\title{
A EXTENSÃO DO INSTITUTO DA FALÊNCIA À PESSOA NATURAL ENQUANTO MECANISMO DE TUTELA DO CONSUMIDOR SUPERENDIVIDADO
}

\author{
THE EXTENSION OF BANKRUPTCY INSTITUTE TO INDIVIDUALS AS A \\ PROTECTION MECHANISM OF THE INDEBTEDNESS CONSUMER
}

\author{
${ }^{1}$ Ana Cristina Alves de Paula
}

\section{RESUMO}

O presente artigo busca analisar a amplitude dos efeitos jurídicos produzidos pelo superenvidividamento do consumidor civil, quando este vier a se encontrar em situação na qual não seja capaz de efetuar o pagamento de suas dívidas sem que reste ameaçado o princípio da dignidade da pessoa humana e o mínimo existencial. Defender-se-á que apenas o instituto da falência da pessoa natural poderá garantir aos credores do devedor civil insolvente uma satisfação isonômica de seus créditos e, concomitantemente, resguardar a dignidade do devedor.

Palavras-chave: Falência da pessoa natural, Superendividamento do consumidor, Insolvência civil

\begin{abstract}
This article seeks to analyze the scope of the legal effects produced by the civil consumer overindebtednes when he founds himself in a situation in which he's not able to pay his debts without threatening the principle of human dignity and the existential minimum. It will be argued that only the natural person's bankruptcy institute can guarantee to creditors of the insolvent debtor civil isonomic satisfaction of their credits and, simultaneously, protect the dignity of the debtor.
\end{abstract}

Keywords: Failure of the natural person, Consumer overindebtedness, Civil insolvency

\footnotetext{
${ }^{1}$ Mestranda em Direito (Franca) na Universidade Estadual Paulista Júlio de Mesquita Filho - UNESP, São Paulo, SP. E-mail: a.cris.direito@gmail.com.
} 


\section{INTRODUÇÃO}

Fruto da massificação do consumo típico das sociedades capitalistas, emerge o crédito como um dos principais meios de viabilizar a felicidade do homem moderno, cristalizada na aquisição de bens tipicamente de consumo provenientes de uma publicidade agressiva geradora de necessidades artificiais. A cultura do endividamento, agravada pela liberalização do crédito de forma desmedida nas sociedades do consumo massificado, especialmente no Brasil, deu ensejo ao fenômeno do superendividamento, grave problema de cunho social que, dada a sua amplitude, merece ser analisado não apenas no âmbito sociológico e individual, mas também no âmbito coletivo e jurídico.

O superendividamento, condição exclusiva de pessoa natural que se vê impossibilitada, de uma forma durável ou estrutural, de pagar o conjunto de suas dívidas, vem atrelado à facilitação do crédito pela iniciativa privada, chancelada pelas políticas públicas, ultrapassando os limites do impacto individual. Entre os motivos que levam o consumidor ao superendividamento, destacam-se a assimetria de informações e os abusos perpetrados pelos bancos e demais instituições financeiras fornecedoras de crédito, apoiados na concessão irresponsável de crédito e na facilitação ao consumismo. Por isso é que o fenômeno deve ser estudado como um problema social do Brasil, assolado pelo consumo extremo, endividamento constante da população, má distribuição de rendas e pela transformação do indivíduo em instrumento de consumo. Apesar de lege lata o ordenamento pátrio oferecer instrumentos para lidar com o superendividamento, não há propriamente um tratamento específico na exata medida das necessidades dos superendividados.

Durante toda evolução da história, sempre houve uma preocupação em criar uma Lei que recuperasse o empresário individual e a sociedade empresária, de modo a evitar o agravamento da situação de crise, com vistas a preservar a empresa, sua produção e os postos de trabalho, fazendo com que o giro empresarial voltasse a sua normalidade e todos os credores fossem pagos. A nova legislação falimentar foi introduzida no ordenamento jurídico nacional pela Lei $\mathrm{n}^{\circ} 11.101$ de 09 de fevereiro de 2005, objetivando a preservação da empresa juntamente com seus ativos e recursos produtivos, a valorização de sua função social e sua reintegração ao mercado e o estímulo à atividade econômica.

O superendividamento no Brasil, diante da anomia, fenômeno jurídico em que inexiste legislação específica protetiva do superendividado, é singular porque o consumidor, por sua vez, também não se prevalece do processo de insolvência civil individual previsto no 
Código de Processo Civil Brasileiro e, ao mesmo tempo, não existe, para o indivíduo comum, um instrumento jurídico tal como a recuperação judicial ou a falência criada para as empresas.

O principal objetivo desta pesquisa será compreender e delimitar o atual debate que envolve o fenômeno do superendividamento do consumidor e demonstrar que, independentemente dos diferentes pressupostos, requisitos e efeitos, apenas o instituto da falência é que poderia garantir o dever de indenizar quando aquele que descumpre culposamente a avença contratual é pessoa natural, fazendo nascer para o credor o direito de usufruir dos meios coercitivos do Estado para ver cumprida a obrigação contraída, desde que resguardada a dignidade do devedor, introduzindo normas que conferem diversas possibilidades de proteção à sua subsistência. Buscou-se, na doutrina estrangeira, parâmetros de proteção legal do superendividado, elegendo-se o modelo francês e norte-americano como perfeitamente compatíveis com o sistema protetivo extrajudicial e judicial do consumidor no Brasil.

Pecou o legislador ao não prever a extensão do processo falencial à pessoa natural, o qual poderia lhe proporcionar algumas vantagens, tais como a possibilidade de, num único processo, solucionar todas as suas pendências e ver cumpridos todos os seus compromissos num lapso de tempo muito menor ao da prescrição civil. Com esta nova perspectiva e advertindo que o assunto merece maior digressão que estas poucas linhas podem conter, ao final, este trabalho apresentará algumas sugestões para a prevenção, tratamento e enfrentamento do superendividamento.

Por fim, para a elaboração desta pesquisa, o método de abordagem utilizado foi o método dedutivo. Utilizou-se também a técnica de pesquisa bibliográfica, com vistas à revisão de literatura e ao resgate do que tem sido produzido acerca do tema deste estudo.

\section{O SUPERENDIVIDAMENTO DA PESSOA NATURAL}

As transformações havidas no processo produtivo desde a Revolução Industrial e, principalmente, após a revolução tecnológica (fenômeno decorrente do grande desenvolvimento técnico alcançado no pós Segunda Guerra Mundial) ocasionaram uma profunda alteração nas relações de consumo. Com efeito, a nova realidade fática percebida na sociedade de consumo é a contração do crédito como meio de viabilizar a felicidade do homem moderno, cristalizada na aquisição de bens tipicamente de consumo provenientes de uma publicidade agressiva geradora de necessidades artificiais. Mas as consequências da 
contração indiscriminada do crédito demonstram a outra face da sociedade de consumo: o endividamento excessivo e o risco da falência pessoal do consumidor. (MORKING, 2015)

Diante dessa nova conjuntura, verificou-se que o consumidor estava desassistido, e por isso, necessitava de uma proteção legal, pois é utópica a possibilidade de auto composição entre os integrantes das relações de consumo sem a intervenção estatal. Baseado nessa vulnerabilidade do consumidor, foi iniciado um movimento no âmbito internacional com o intuito de reequilibrar as relações entre consumidores e produtores. No ano de 1985 a ONU, pela Resolução n $39 / 248$, "baixou norma sobre a proteção do consumidor (...) reconhecendo expressamente 'que os consumidores se deparam com desequilíbrios em termos econômicos, níveis educacionais e poder aquisitivo'". (BRITO, 2006).

No ordenamento jurídico brasileiro, desde a Constituição da República de 1988, a defesa do consumidor adquiriu status de direito e garantia fundamental, conforme seu art. $5^{\circ}$, XXXII, bem como foi insculpida entre os princípios conformadores da ordem econômica nacional, nos termos do art. 170, inc. V. Neste contexto, o legislador constitucional impôs um verdadeiro dever de legislar ao Congresso Nacional, determinando, no art. 48 do ADCT, a elaboração do Código de Defesa do Consumidor. Em 11 de setembro de 1990, foi promulgada a Lei $n^{\circ}$ 8.078/90 (Código de Defesa do Consumidor), fundamentalmente principiológica, visto que construída em torno de princípios que norteiam e impregnam todos os artigos do citado diploma legal. Editada com o fulcro de equilibrar as relações jurídicas travadas entre consumidores e fornecedores, tem como ponto principal a proteção da parte mais fraca da relação - o consumidor.

O CDC abriga as relações de consumo, criando um microssistema próprio para resolução de conflitos desta natureza, na pertinente lição do professor Gustavo Tepedino. (TEPEDINO, 2012). A qualidade de microssistema é atribuída pela multidisciplinariedade que abrange as normas consumeristas, uma vez que, para proteger o vulnerável, o CDC busca inspiração nas normas penais (crimes de consumo previstos nos arts. 61 a 80), nas normas administrativas (infrações administrativas constantes nos arts. 55 a 60), além das normas civis imiscuídas nos demais artigos.

O intuito preventivo da lei está no fundado reconhecimento da desigualdade entre consumidor e fornecedor nas relações de consumo, sendo correto afirmar que o Código de Defesa do Consumidor é expressão do princípio da isonomia material, pois trata desigualmente os sujeitos da relação de consumo na medida em que se diferenciam. (TEIXEIRA, 
O caput do art. $4^{\circ}$ da Lei $n^{\circ} 8.078 / 90$ é claro ao estabelecer que o fim supremo das relações de consumo deve ser o atendimento efetivo aos anseios e necessidades dos consumidores, devendo possuir total observância valores como o respeito à sua dignidade, bem como a proteção de seus interesses econômicos, sendo ressaltado o aspecto da transparência e harmonia das relações de consumo.

\footnotetext{
Art. $4^{\circ}$. A Política Nacional das Relações de Consumo tem por objetivo o atendimento das necessidades dos consumidores, o respeito à sua dignidade, saúde e segurança, a proteção de seus interesses econômicos, a melhoria da sua qualidade de vida, bem como a transparência e harmonia das relações de consumo, atendidos os seguintes princípios:

I - reconhecimento da vulnerabilidade do consumidor no mercado de consumo;
}

A análise do supracitado artigo permite constatar a clara orientação normativa no sentido de que o equilíbrio nas relações de consumo deve possuir observância completa, partindo-se do pressuposto de que o consumidor é a parte mais frágil da relação, além de sua proteção concretizar um patamar de harmonia entre os princípios constitucionais da liberdade econômica, da justiça social.

\section{CONCEITO JURÍDICO DE SUPERENDIVIDAMENTO}

No período pós-crise do subprime, deflagrada nos Estados Unidos da América, no ano de 2007, com ápice em 2008, oriunda da explosão de inadimplemento causada pelas concessões de crédito hipotecário a pessoas de baixa ou sem nenhuma renda (que realizaram a segunda ou terceira hipoteca sobre o imóvel próprio ou financiado e foram surpreendidas por dívidas superiores ao valor venal do bem), o Brasil adotou uma política econômica expansionista, ao elevar a oferta de crédito para financiar as necessidades de consumo dos indivíduos, apostando que o crescimento da renda, futuramente, pudesse compensar o aumento do endividamento das pessoas. No entanto, tal situação não se define como sustentável no longo prazo, dado que o efeito de alavancagem do poder de compra de consumo tende a colocar as pessoas em uma situação de endividamento excessivo. (METTE, 2014).

Constantemente aumenta o número de pessoas que assumem dívidas excessivas e não conseguem quitá-las. A cultura do endividamento, agravada pela liberalização do crédito de forma desmedida ao consumidor, seja com parcelamentos longos, seja pela facilitação do crédito com desconto em folhas, seja pela abertura de contas bancárias com crédito anexo 
para pessoas de baixa renda, seja através da inclusão de milhões de aposentados, com descontos de seus benefícios, sem qualquer limite ou reserva de um mínimo existencial de digidade (restre à vivre), no Brasil, deu ensejo ao fenômeno do superendividamento, grave problema de cunho social que, dada a sua amplitude, merece ser analisado não apenas no âmbito sociológico e individual, mas também no âmbito coletivo e jurídico.

Não se pretende aqui negar que o crédito seja essencial à gestão da vida moderna na sociedade capitalista. O crédito é, sem dúvidas, benéfico ao consumidor, pois ele possibilita e democratiza a aquisição de bens necessários ao ser humano. Mas, se de um lado o crédito é considerado a alavanca da economia de mercado, do outro seus efeitos negativos são cada vez mais perceptíveis no seio da chamada sociedade de consumo, desencadeando o fenômeno superendividamento que, no caso concreto, acaba por resultar numa espécie de "morte civil", caracterizada como a morte do "homo economicus", já que, não tendo condições de quitar suas dívidas, o consumidor é excluído do mercado de consumo. (GONTIJO, 2010).

A expressão "superendividamento" foi emprestada da doutrina francesa, que a utilizou apenas para designar a quantidade das dívidas, sendo que "super" do latim, significa "muito". A doutrina brasileira não se utilizou da expressão sobreendividado, pois nesta expressão está uma conotação de "doentio".

No entendimento de Maria Manuel Leitão Marques, o superendividamento é:

Designado por falência ou insolvência de consumidores, refere-se às situações em que o devedor se vê impossibilitado, de uma forma durável ou estrutural, de pagar o conjunto das suas dívidas, ou mesmo quando existe uma ameaça séria de que não possa fazer no momento em que elas se tornem exigíveis. (MARQUES, 2000).

Como nas palavras da professora Cláudia Lima Marques, define-se superendividamento

[...] a impossibilidade global de o devedor pessoa física, consumidor, leigo e de boafé, pagar todas suas dívidas atuais e futuras de consumo (excluídas as dívidas com o fisco, oriundas de delitos e de alimentos). (MARQUES, 2008).

Já para a Comissão de Direitos do Consumidor da União Europeia, define-se o superendividamento como "uma condição em que as pessoas são incapazes de pagar suas dívidas com a própria renda" (SOARES, 2012). Coaduna-se, neste trabalho, com a definição de superendividamento como

Um fenômeno social, que atinge o consumidor de crédito, pessoa física, que, agindo de boa-fé, voluntariamente ou em virtude de fatos da vida, contrai dívidas, cujo total, incluindo vencidas e a vencer, compromete o mínimo existencial garantido constitucionalmente. (CAMPOS, 2015).

Ressaltando que o superendividamento é um fenômeno tanto social quanto jurídico, Giancoli Brunno Pandori verifica que 
O superendividamento do consumidor surge como a face negra da democratização do crédito ao consumo. Tão antigo como a história do crédito, esse fenômeno tornou-se um problema coletivo relevante quando da massificação do crédito. Por isso, ele deve ser encarado tanto como um problema social, como um problema jurídico, justamente porque a ideia de ser devedor sempre esteve associada ao sentimento de fracasso, de infelicidade, de pobreza, de indignidade humana. (PANDORI, 2008).

Cumpre salientar que o fenômeno do superendividamento nos países de common law é entendido como risco inerente ao à expansão do mercado financeiro, em outras palavras, como um mal necessário da sociedade consumerista. Neste sistema, a solução do problema é socializada, perdoando-se a dívida após a liquidação dos bens. (GONTIJO, 2010). De outro lado se encontra a doutrina dos países de civil law, segundo a qual o superendividado não só é vítima do sistema, mas também é culpado pela imprudência e má administração do orçamento. Seguindo essa visão, o devedor passa por um processo de reeducação, em que suas dívidas são renegociadas, apenas sendo perdoadas em caso extremo. (MENEZES JÚNIOR, 2014). Na opinião de Felipe Kirchner, "a vantagem do primeiro modelo é permitir ao devedor reiniciar sua vida sem encargos do passado; a do segundo, responsabilizá-lo pelos compromissos assumidos, potencializando a prevenção". (MENEZES JÚNIOR, 2014). Segundo o autor, a desvantagem do primeiro sistema é perdoar as dívidas de quem poderia pagá-las, e a do segundo, seria a não adequação a todos os casos de superendividamento.

Discursar sobre o fenômeno do superendividamento no Brasil já não é novidade. Vários são os apelos da doutrina que apontam não só a emergência do problema no país, mas igualmente a necessidade de estudá-lo para conferir-lhe tratamento específico e lhe evitar as consequências nefastas. Entremeiam-se no estudo do superendividamento inevitavelmente conhecimentos de natureza sociológica, ética, política, psicológica, econômica e jurídica.

Pode-se concluir, portanto, que embora o crédito para o consumo se apresente, de um lado, como motor do processo capitalista, financiando a atividade econômica, de outro, é fonte de abusos por parte do fornecedor, ensejando a elaboração de novas teorias e normas disciplinadoras dessa relação. Por tal motivo, o estudo do fenômeno social oriundo das relações de consumo - o superendividamento do consumidor - remete à transposição do paradigma econômico clássico de que o consumidor é livre e racional na realização do ato de compra e que, portanto, deve arcar com a consequência de sua conduta no mercado de consumo. (OLIVEIRA, 2011). Verifica-se ainda que a falta de legislação para enfrentar referido fenômeno acaba provocando consequências trágicas no ordenamento jurídico dos países que ainda não o fizeram, sendo uma delas, a total destruição da dignidade do superendividado e de sua família, que já se constatou ter perfil de pessoa responsável, que 
tenta manter condições de consumo de sua família, na imensa maioria das vezes, desinformada quanto as condições do contrato. (MENEZES JÚNIOR, 2014).

\section{EFEITOS DA DECLARAÇÃO DE FALÊNCIA DA PESSOA NATURAL NUMA PERSPECTIVA LEGE FERENDA}

A Lei $\mathrm{n}^{\circ}$ 11.101/05, tida como um tratamento específico para a situação de crise, atualmente se aplica especificamente aos empresários (quem exerce profissionalmente atividade econômica organizada para a produção ou circulação de bens ou de serviços e os prestadores de serviços intelectuais, de natureza científica, literária ou artística, se o exercício da profissão constituir elemento de empresa - vide art. 966/CC) e sociedades empresárias (as que tenham por objeto o exercício de atividade própria de empresário sujeito a registro, salvo as exceções expressas, e a sociedade por ações - vide arts. 981 e 982, do Código Civil de 2002), com vistas a garantir a tutela coletiva dos credores. Contudo, algumas organizações, mesmo sendo reputadas empresariais, são excluídas do regime jurídico falimentar, parcial ou totalmente. A referida legislação não se aplica, ainda, às pessoas naturais não registradas como empresárias, sociedades simples, sociedades cooperativas (independentemente do objeto), associações e fundações, reguladas pelo Código de Processo Civil. Se se tornarem insolventes, sujeitar-se-ão à execução por quantia certa e à declaração de insolvência civil.

O presente estudo se filia à corrente de Ugo Rocco que, com sua obra Naturaleza del Processo de Quiebra y de La Sentencia que declara La Quiebra, permite a qualificação da falência da pessoa natural como procedimento especial ao auxiliar o consumidor superendividado a adimplir as dívidas para com as quais se obrigou, já que a falência propriamente dita é muito mais do que um procedimento de quebra e até mesmo executivo e expropriatório. (THEODORO JUNIOR, 1980).

Embora exista previsão acerca da insolvência civil desde 1973, a sentença raramente é proferida. Firmou-se, portanto, a plena descrença no instituto de insolvência civil, seja ela necessária ou voluntária, pois ainda que prevista sua possibilidade no novo estatuto processual civil, dificilmente será ela adotada pelos credores ou até mesmo pelo próprio devedor, em razão das péssimas consequências que acarreta para ambos os polos da relação jurídica. Aliás, Homero Francisco Tavares Júnior, citando Pontes de Miranda, salienta que este afirmou que "o instituto da insolvência civil, em toda a sua plenitude, não penetrou no direito brasileiro". (MIRANDA, 1976). 
O procedimento concursal pode ser entendido como uma liquidação forçada, em que o Estado intervém para afastar (ou relativizar) a autonomia do credor na condução de seu negócio e na própria liquidação do ente empresarial, visando à solução do estado de crise econômica. Há um temperamento entre os poderes dos credores (no processamento dos meios de falência por meio de instituições criadas, tais como a Assembleia Geral de Credores e o Comitê de Credores) e o interesse do Estado na preservação da função econômica e social daquela unidade produtiva. (THEODORO JUNIOR, 1980).

Primeiramente, para ingresso da ação declaratória de falência, devem ser observados os requisitos da petição inicial, como em qualquer processo, junto da comprovação do efetivo status de superendividamento do consumidor devedor. No caso de autofalência (instituto previsto no art. 105 da Lei $\mathrm{n}^{\circ}$. 11.101/2005, que também assegura ao devedor empresário que julgue não atender aos requisitos para pleitear sua recuperação judicial a possibilidade de requerer ao juízo sua falência), o devedor deverá fazer menção a todas suas dívidas em aberto, bem como indicar os respectivos credores, e, no caso de falência requerida pelo credor, este também deverá indicar o seu crédito em relação ao devedor. Se possível, em ambos casos, os títulos que embasam a pretensão deverão acompanhar a peça inaugural. Como não existe execução coletiva sem título executivo, deverá haver um processo de conhecimento que passe pela fase de instrução, tal qual ocorre com qualquer processo ordinário, para apuração da situação de superendividamento do devedor.

Com a decretação da falência, formar-se-á um juízo universal de credores. Como assevera o doutrinador Gladston Mamede,

[...] todas as diversas pretensões de receber créditos contra o devedor, empresário ou sociedade empresária, estarão submetidas a um único juízo e, neste, a um único processo. (MAMEDE, 2013).

A verificação dos créditos segue o mesmo rito será realizada pelo Administrador Judicial, que, num primeiro momento, fará a devida análise das dívidas do consumidor superendividado, além de outros documentos quaisquer que lhe forem apresentados pelos credores ou terceiros. Nesse trabalho de apuração, o Administrador Judicial poderá contar com o auxílio de colaboradores, inclusive profissionais ou empresas especializadas (art. $7^{\circ}$ ). Feita essa apuração preliminar, será publicada a primeira lista de credores, contendo a relação nominal, valores atualizados e classificação de seus respectivos créditos. Ela constará do edital que noticia o processamento do pedido de recuperação judicial ou que a falência foi decretada (art. 52, $\S 1^{\circ}$, ou art. 99, parágrafo único, respectivamente). 
A relação apresentada pelo administrador judicial, ao contrário do parecer do sindico ou do comissário, próprios do antigo regime falimentar, passa a ter força vinculante. A partir dessa primeira lista, publicado o edital, os credores terão o prazo de 15 dias para apresentar ao administrador judicial suas habilitações ou suas divergências quanto aos créditos relacionados, inclusive instruindo-as com os documentos pertinentes (art. $7^{\circ}, \S 1^{\circ}$ ). Esse pedido deverá ser feito de maneira detalhada, indicando origem, documentos probatórios, especificação do objeto e tudo que for necessário. (ARNOLDI, 2007).

O administrador judicial, com base nas informações e documentos colhidos na verificação e habilitação de créditos, completará ou alterará a relação de credores e créditos, publicando-a na forma de uma segunda lista, no prazo de 45 dias, contado do final daquele prazo de 15 dias. Neste edital, serão indicados o local, o horário e o prazo comum em que o Comitê, qualquer credor, o devedor ou seus sócios ou o Ministério Público terão acesso aos documentos que fundamentaram a elaboração dessa relação (art. $7^{\circ}, \S 2^{\circ}$, da Lei $n^{\circ}$ 11.101/05). (ARNOLDI, 2007).

No prazo de dez dias, a partir da publicação da nova relação de credores, as pessoas acima listadas podem apresentar ao juiz impugnação contra a relação de créditos verificados e habilitados, apontando a ausência de qualquer crédito ou manifestando-se contra a legitimidade, importância ou classificação de crédito relacionado. A impugnação será dirigida ao juiz por meio de petição, instruída com os documentos que tiver o impugnante, o qual indicará as provas consideradas necessárias (art. 13 da Lei n 11.101/05). Cada impugnação será autuada em separado, com os documentos a ela relativos, reunindo-se em uma mesma autuação todas as impugnações que versem sobre o mesmo crédito (art. 13, parágrafo único, da Lei ${ }^{\circ}$ 11.101/05). (ARNOLDI, 2007).

Os credores cujos créditos forem impugnados serão intimados para contestar a impugnação, juntando os documentos que tiverem e indicando outras provas que reputem necessárias, em cinco dias (art. 11). Depois desse prazo, o devedor e o Comitê de Credores, se houver, serão intimados pelo juiz para se manifestar sobre ela no prazo comum de cinco dias (art. 12, caput, da Lei $\left.\mathrm{n}^{\circ} 11.101 / 05\right)$.

Diferentemente do art. 89 do Dec.-Lei $n^{\circ} 7.661 / 45$, o novo estatuto legal é silente quanto à possibilidade do impugnante desistir da impugnação ofertada. Conforme ensinamento da doutrina, desde que o impugnante pague as despesas devidas, é lícito desistir de sua impugnação. Porém, se o impugnante optar por manter a sua impugnação, findo o prazo referido, o administrador judicial será intimado pelo juiz para emitir parecer no prazo de cinco dias, devendo juntar à sua manifestação o laudo elaborado pelo profissional ou empresa 
especializada, se for o caso, e todas as informações existentes nos livros fiscais e demais documentos do devedor acerca do crédito, constante ou não da relação de credores, objeto da impugnação (art. 12, parágrafo único, da Lei n 11.101/05).

Feita a instrução desses processos, os autos de impugnação serão conclusos ao juiz, que (art. 15 da Lei $\left.\mathrm{n}^{\circ} 11.101 / 05\right)$ :

I - determinará a inclusão no quadro-geral de credores das habilitações de créditos não impugnadas;

II - julgará as impugnações que entender suficientemente esclarecidas pelas alegações e provas apresentadas pelas partes, mencionando, de cada crédito, o valor e a classificação;

III - fixará, em cada uma das restantes impugnações, os aspectos controvertidos e decidirá as questões processuais pendentes;

IV - determinará as provas a serem produzidas, designando audiência de instrução e julgamento, se necessário.

Em relação às impugnações que não se incluírem no quadro geral de credores, o juiz determinará, para fins de rateio, a reserva de valor para satisfação do crédito impugnado. Por outro lado, sendo parcial, a impugnação não impedirá o pagamento da parte incontroversa (art. 16, caput e parágrafo único, da Lei n 11.101/05). (ARNOLDI, 2007).

Da decisão judicial que julga a impugnação caberá agravo de instrumento (art. 17, caput - vide art. 522 do CPC). Recebido o agravo, será distribuído incontinenti, sendo que o relator poderá conceder efeito suspensivo à decisão que reconhece o crédito ou determinar a inscrição ou modificação do seu valor ou classificação no Quadro Geral de Credores, para fins de exercício de direito de voto em Assembleia Geral (art. 17, parágrafo único, da Lei $\mathrm{n}^{\circ}$ 11.101/05). Se não houver impugnações, ou julgadas estas pelo Juiz, deverá o Administrador providenciar a consolidação do Quadro Geral de Credores, a ser homologado pelo juiz, com a menção da importância e da classificação de cada crédito na data do requerimento da recuperação judicial ou da decretação da falência, conforme verificações e habilitações e a decisão proferida nas impugnações oferecidas (art. 18, caput).

Além disso, o administrador judicial diante do processo de falência ou da recuperação judicial tem fundamental importância, portanto, deverá atentar para as seguintes regras:

a) enviar correspondência aos credores constantes na relação enviada pelo devedor comunicando a data do pedido de recuperação judicial ou da decretação da falência, a natureza, o valor e a classificação dada ao crédito; 
b) fornecer, com presteza, todas as informações pedidas pelos credores interessados;

c) dar extratos dos livros do devedor, que merecerão fé de ofício, a fim de servirem de fundamento nas habilitações e impugnações de créditos;

d) exigir dos credores, do devedor ou seus administradores quaisquer informações;

e) elaborar a relação de credores e publicar, indicando o local, o horário e o prazo comum em que as pessoas indicadas terão acesso aos documentos que fundamentaram a elaboração dessa relação;

f) consolidar o quadro geral de credores que será homologado pelo juiz com base na relação de credores e nas decisões proferidas nas impugnações oferecidas.

g) requerer ao juiz a convocação da Assembleia Geral de credores nos casos previstos na lei ou quando entender necessária sua ouvida para tomada de decisões;

h) contratar mediante autorização judicial, profissionais ou empresas especializadas para, quando necessário, auxiliá-lo no exercício de suas funções;

i) manifestar-se nos casos previstos na lei.

O Quadro Geral de Credores será juntado aos autos e publicado no órgão oficial, no prazo de cinco dias, contados da data da decisão que houver julgado as impugnações. O juiz decidirá, portanto, a relação correta de credores. (ARNOLDI, 2007). Trata-se de um procedimento de vital importância, pois, sem habilitar seu crédito no procedimento coletivo, o credor não poderá exercer os direitos respectivos. No sistema de 1945, tal ato estava compreendido na esfera de atribuições do síndico, a quem cabia o ônus de expedir circulares a cada um dos credores e entregá-las por via postal ou em mãos e, posteriormente, comprovar judicialmente o cumprimento dessa obrigação. $\mathrm{O}$ atual sistema estabelece que a convocação dos credores por edital destina-se à eficiência do procedimento, contribuindo com a celeridade dos processos de verificação dos créditos. (ARNOLDI, 2007).

De acordo com o art. $9^{\circ}$, a habilitação de crédito, realizada pelo credor (não sendo necessário advogado), deverá conter:

I - o nome, o endereço do credor e o endereço em que receberá comunicação de qualquer ato do processo;

II - o valor do crédito, atualizado até a data da decretação da falência ou do pedido de recuperação judicial, sua origem e classificação;

III - os documentos comprobatórios do crédito e a indicação das demais provas a serem produzidas - os títulos e documentos que legitimam os créditos deverão ser exibidos no original ou por cópias autenticadas se estiverem juntados em outro processo; 
IV - a indicação da garantia prestada pelo devedor, se houver, e o respectivo instrumento;

$\mathrm{V}$ - a especificação do objeto da garantia que estiver na posse do credor.

O prazo para habilitação de créditos é de quinze dias, contados da divulgação da primeira lista de credores. Os credores, todavia, durante a tramitação dos processos de falência ou de recuperação judicial, podem, por desídia quanto aos prazos do edital, por desconhecimento deste ou até por falta de documentação, deixar de habilitar seus créditos no prazo legal de 15 dias após a publicação do edital. Nesse contexto, tal como já ocorria sob a égide do estatuto legal anterior, não sendo observado o prazo estipulado, a habilitação de crédito será recebida como retardatária (art. 10 da Lei $\mathrm{n}^{\circ}$ 11.101/05).

Os credores que apresentarem habilitações retardatárias (fazendo-se necessário um advogado para tal intento) não perdem o direito à habilitação, nem ao recebimento de seus créditos, que se localizarão abaixo dos créditos quirografários na ordem de preferência para pagamento. Todavia, não terão direito a voto nas deliberações da Assembleia Geral de credores em caso de recuperação judicial, excetuados os titulares de créditos derivados da relação de trabalho, que preservam esse seu direito, a partir do momento em que tiver seu crédito habilitado. (ARNOLDI, 2007).

As habilitações de crédito retardatárias, se apresentadas antes da homologação do quadro geral de credores, serão recebidas como impugnação e processadas na forma dos arts. 13 a 15 desta Lei. Após a homologação do Quadro Geral de Credores, aqueles que não habilitaram seu crédito poderão, observado, no que couber, o procedimento ordinário previsto no Código de Processo Civil, requerer ao juízo da falência a retificação do Quadro Geral para inclusão do respectivo crédito (art. $10, \S \S 5^{\circ}$ e $6^{\circ}$, da Lei $n^{\circ} 11.101 / 05$ ). Considerar-se-ão automaticamente habilitados os créditos remanescentes da recuperação judicial, quando definitivamente incluídos no quadro-geral de credores, tendo prosseguimento as habilitações que estejam em curso (art. 80 da Lei $\left.n^{\circ} 11.101 / 05\right)$.

Por previsão do art. 19, o administrador judicial, o Comitê, qualquer credor ou o representante do Ministério Público poderá, até o encerramento da falência, observado, no que couber, o procedimento ordinário previsto no Código de Processo Civil, pedir a exclusão, outra classificação ou a retificação de qualquer crédito, nos casos de descoberta de falsidade, dolo, simulação, fraude, erro essencial ou, ainda, documentos ignorados na época do julgamento do crédito ou da inclusão no quadro geral de credores. Trata-se de verdadeira ação rescisória da decisão que julga a impugnação de crédito ou acolhe habilitação, que até o 
encerramento da falência ou da recuperação judicial somente se constituirá em coisa julgada formal. (ARNOLDI, 2007).

Proposta a ação pedindo a exclusão, outra classificação ou a retificação do crédito, o pagamento ao titular do crédito por ela atingido somente poderá ser realizado mediante a prestação de caução no mesmo valor do crédito questionado. A ação rescisória falimentar será proposta exclusivamente perante o juízo da falência ou, nas hipóteses previstas no art. $6^{\circ}, \S \S$ $1^{\circ}$ e $2^{\circ}$, desta Lei, perante o juízo que tenha originariamente reconhecido o crédito (art. $19, \S \S$ $1^{\circ}$ e $\left.2^{\circ}\right)$. Da decisão cabe recurso de apelação.

Diante dessas peculiaridades, pode-se concluir que o processo de falência, embora constitua um processo predominantemente executivo, não é, todavia, um processo puramente executivo, já que para atingir seu principal objetivo, o órgão judiciário deve desempenhar ampla atividade cognitiva. Como decorrência, destaca-se a salutabilidade da proposta aqui realizada, tendo em vista que a falência demandaria o pagamento das dívidas do consumidor superendividado com os recursos patrimoniais penhoráveis que ele possuir, ainda que a dívida seja muitas vezes maior que o valor dos bens.

A Lei $\mathrm{n}^{\circ}$ 11.101/05, com seus inovadores conceitos de "recuperação", oferece subsídios oportunos para a formulação de estruturas ou princípios específicos ao tratamento de consumidores superendividados, especialmente com a proposição de facilidades a serem concedidas ao devedor, tais como a livre elaboração de um plano de escalonamento de dívidas em concerto com os credores e a concessão de prazos de recuperação. Já a imposição de se conferir ampla publicidade ao procedimento parece menos adequada ao tratamento do superendividamento.

A decretação de falência da pessoa natural pode ser usada não somente como forma de execução, mas sim como ferramenta, a fim de compelir o devedor a saldar seus débitos, podendo causar a desistência da execução singular em detrimento da execução coletiva. Não se pode dizer que só é superendividado o devedor quando este inadimplir suas obrigações contraídas, a exemplo do que ocorreria na autofalência, quando o próprio devedor, antes mesmo de que ocorra o inadimplemento de suas obrigações, poderá requerer ao juiz sua declaração de falência.

É preciso que o Direito Brasileiro adote medidas legislativas que tenham por objetivo específico a diminuição dos perigos que envolvem as operações de crédito ao consumo, indo além daquelas já instituídas pelo CDC. Não é possível a simples importação de um modelo de insolvência civil para implantá-lo em sistema diverso. O modelo deve ser adaptado para o contexto do sistema legal protetivo do país que pretende implantar uma legislação específica 
de superendividamento. Ele necessita de se amoldar na sociedade em que está sendo adotado, sendo desenvolvido para trabalhar a partir de uma perspectiva prática que precisa levar em consideração a disponibilidade ou não de uma estrutura extrajudicial de tratamento que capacite e treine conselheiros e mediadores de superendividamento e principalmente a sensibilidade e capacidade do Poder Judiciário de absorver essa nova demanda de processos de insolvência.

Embora o direito nunca possa ser comparado sem que se analise a cultura jurídica, o sistema institucional de aplicação e o ambiente social em que vigora, uma visão das legislações de diversos países pode ser uma porta de entrada importante para uma primeira abordagem deste problema do crédito ao consumo.

O Code de la Consommation francês prevê duas fases de tratamento do superendividamento. Caso classificada como superendividamento clássico, buscar-se-á, na fase administrativa, a elaboração de um plano amistoso, com ampla liberdade de negociação com os credores. (ARNOLDI, 2007). Frustrado tal plano, a Comissão de Superendividamento recomenda ao juízo da execução medidas ordinárias, que compreendem o reparcelamento das dívidas e a redução ou imputação dos juros vincendos sobre o capital devido. (PEREIRA, 2007). Se, diversamente, a situação indicar caso de insolvência por inexistência de patrimônio suficiente, de modo a frustrar as recomendações ordinárias, a Comissão pode recomendar medidas extraordinárias, as quais incluem suspensão judicial das execuções em curso, moratória de até dois anos, a cujo termo, persistindo a insolvência, pode-se proclamar a eliminação parcial do conjunto das dívidas. (PEREIRA, 2007).

Mas se a situação do devedor indicar situação irremediavelmente comprometida, caracterizada pela impossibilidade manifesta de cumprimento das medidas acima referidas, inicia-se a fase judicial mediante o procedimento denominado restabelecimento pessoal. Trata-se de espécie de concurso universal de credores que inclui, resumidamente, a publicação de edital de chamamento a credores, a liquidação do ativo apurado - não sem se considerar um mínimo vital, o reste à vivre destinado à subsistência do devedor - e, finalmente, a eliminação da totalidade das dívidas. Após o procedimento, o consumidor é considerado apto para um nouveau départ. (PEREIRA, 2007).

Os Estados Unidos da América também reconheceram a vulnerabilidade dos consumidores diante do crédito. Em 2009, o Senado norte-americano aprovou o Credit Card $A c t$, que regula o fornecimento de crédito, restringindo a oferta para consumidores vulneráveis como famílias de baixa renda e jovens universitários. A referida legislação prevê, para o tratamento do superendividamento, dois procedimentos: a liquidação no capítulo $7^{\circ}$ 
(straight bankruptcy) e o ajustamento de dívidas no capítulo 13 (reorganization). (PEREIRA, 2007). A solução prevista no capítulo $7^{\circ}$ não envolve a apresentação de um plano de pagamento, cabendo ao administrador da falência reunir e vender os bens não isentos do devedor e distribuir o produto arrecadado para pagar aos credores. A parte dos bens do devedor sujeita a penhoras e hipotecas estará afetada exclusivamente a estes credores privilegiados. Além disso, o Código de Falências permite ao devedor manter certos bens de valor inferior à isenção do Estado, mas o administrador liquidará os bens remanescentes do devedor.

Pelo procedimento do capítulo 13, o devedor de boa-fé pode se apresentar perante o Tribunal de Falências e obter a confirmação de um plano geral de pagamento de suas dívidas, caso seja aceito pelos credores e não sofra objeção do trustee (um oficial encarregado, em cada tribunal, de velar pela efetiva aplicação das normas relativas ao procedimento e de acompanhar o cumprimento dos planos). Ao final do prazo previsto para o cumprimento do plano ou em caso de inexecução do plano, o devedor obterá liberação definitiva de todas as dívidas ali previstas. (PEREIRA, 2007). Pode também o consumidor superendividado recorrer diretamente ao procedimento previsto no capítulo $7^{\circ}$, mediante o qual se obtém, após a liquidação do ativo apurado, a eliminação total (discharge of debts) das dívidas não cobertas por garantia pessoal ou real, excetuadas algumas dívidas de natureza especial. (PEREIRA, 2007).

O Brasil, lamentavelmente, não possui regulamento jurídico do superendividamento, o que demonstra seu atraso legislativo e, em certa medida, o preconceito ideológico que gira em torno do problema. Muito embora tenha sido incorporada na Constituição Federal de 1988 atenção diferenciada aos consumidores e o Código de Defesa do Consumidor, tratando da condição de vulnerabilidade do consumidor, e tenham surgido iniciativas para reforma do Código de Defesa do Consumidor com o objetivo de torná-lo mais atual e próximo da realidade vivenciada hoje pelos sujeitos da relação de consumo, ${ }^{1}$ o Congresso Nacional ainda não aprovou normatização específica sobre a problemática do superendividamento.

A ausência de tratamento legislativo específico de que padece a realidade brasileira

\footnotetext{
${ }^{1}$ Nesse cenário, encontram-se em tramitação no Senado Federal: o PLS n ${ }^{\circ}$ 281/2012, PLS n $282 / 2012$ e PLS $\mathrm{n}^{\circ} 283 / 2012$. Destaca-se também o Projeto de Lei $\mathrm{n}^{\circ} 1.922 / 11$, do deputado Fábio Faria (PMN-RN), pelo qual s pessoas físicas devedoras serão beneficiadas pelo instituto da recuperação judicial, nos moldes do que a Lei de Falências prevê para empresários.
} 
atual faz apelo ao estudo de direito comparado, realizado brevemente no item anterior. A omissão do legislador afeta diretamente a dignidade do cidadão consumidor, que se vê, não raras vezes, sem condições de suprir suas necessidades mais básicas, como saúde e alimentação, em razão do endividamento decorrente dos créditos que lhes foram ofertados e que são cobrados com juros exorbitantes, tornando-se, desta forma impagável. (MENEZES JÚNIOR, 2014).

Sugere-se que se o instituto da falência da pessoa natural vier a ser regulado, ele deveria mesclar o modelo francês ao modelo norte-americano, tratando o superendividamento como um risco associado à expansão do mercado financeiro e, por isso, apostando na socialização do risco de desenvolvimento do crédito com a previsão de uma responsabilidade limitada para o consumidor.

A opção inicial deve ser orientada para a priorização da solução extrajudicial conciliada (preconizada pelo modelo francês) - razão pela qual os conselheiros devem ser recrutados e capacitados para, de forma profissional e independente, perseguir a mediação de acordos de dívida voluntariamente negociados -, para só depois ser adotada a solução judicial (preconizada pelo modelo norte-americano), em que o devedor liquide parte de seu patrimônio ou coloque parte de sua renda futura para pagamento dos credores durante um período máximo pré-estabelecido, não superior a cinco anos, por exemplo.

A priorização da solução extrajudicial tem a vantagem de evitar o requerimento de falência por parte dos consumidores e preservar rendimentos para pagamento dos credores. Questões de dívidas devem ser mantidas fora dos tribunais, tanto quanto possível. Não o sendo, os bens do devedor serão liquidados para o pagamento das dívidas possíveis, com base num plano aprovado judicialmente. Assim, o superendividado poderá preservar parte de seus bens que não necessitem ser liquidados, recebendo o perdão da dívida remanescente em prazo razoável.

A intenção das medidas acima referidas não é conceder privilégios aos maus pagadores, mas sim recompor a situação daqueles que foram prejudicados por situações econômicas imprevisíveis, auxiliando os superendividados que têm interesse em regularizar sua situação. Urge a ruptura do presente modelo, genérico e impreciso de avaliação do risco, pois muitas pessoas enfrentam problemas econômicos graves e não possuem meios capazes de adimplir as obrigações que avençaram, o que não significa dizer que não possuem verdadeira vontade em fazê-lo. 


\section{CONSIDERAÇÕES FINAIS}

Objetivou o presente trabalho colaborar na consolidação de novos paradigmas que afastem a atual situação de incerteza, insegurança e, muitas vezes, injustiça, pela qual passam numerosas unidades de consumo em situação de superendividamento.

Na sociedade contemporânea, a possibilidade de satisfação imediata das necessidades atua poderosamente no processo decisório do consumidor moderno, facilitando a atividade de persuasão do fornecedor para induzir o consumidor às compras irrefletidas e desequilibrar seu cálculo racional de meios e fins. A crise financeira que se vive atualmente pode ser explicada, em parte, pelo fato de que os meios financeiros limitados que a maioria das famílias dispõem as obrigam a recorrer ao crédito para obtenção de bens que supram suas necessidades essenciais e, simultaneamente, permitam exibir alguns sinais de status, face à necessidade de representar uma imagem e um estilo de vida semelhante ao dos grupos de referência social.

Desponta, então, o fenômeno do superendividamento, por força do qual o cidadão, não conseguindo pagar suas dívidas - em razão de situações alheias a sua vontade ou pelo descontrole de suas finanças -, torna-se um excluído social. Ao comprometer antecipadamente sua renda, o cidadão-consumidor se vê diante de um problema de temporalização de suas necessidades, conduzindo-o a alienar cada vez mais seu trabalho futuro, numa espiral de duradouro endividamento.

A problemática do superendividamento do consumidor tem ganhado imenso destaque na seara do direito concursal das mais variadas e modernas legislações, reformadas principalmente após a grande crise econômico-financeira de 2008, como um reflexo do atual panorama econômico, representado pela disponibilização, acesso e preço do crédito, hoje tido como elemento fundamental e, ao mesmo tempo, como um grande risco à saúde econômica das pessoas naturais ou jurídicas e, assim, do Estado, o que demanda renovação da legislação, da doutrina e da prática empresarial.

Fato é que o superendividamento emerge na modernidade como um problema social, econômico e jurídico, ao colocar em risco a própria sobrevivência do consumidor e de sua família, sendo patente a sua incompatibilidade com os ideais de solidariedade e de justiça social e com o respeito da dignidade da pessoa humana. Assim, conclui-se que a situação do indivíduo superendividado não pode continuar a ser ignorada pelo legislador, tendo em vista apresentar-se como um problema de difícil solução, que acomete considerável parcela da população brasileira. 
Apesar da legislação brasileira ter incorporado na Constituição Federal de 1988 atenção diferenciada aos consumidores e o Código de Defesa do Consumidor, o ordenamento consumerista brasileiro carece de uma proteção específica para o caso do consumidor superendividado. Nesse sentido, imprescindível é a criação de uma lei específica que combata e possa dirimir conflitos envolvendo o fenômeno do superendividamento. Aqui as vantagens da comparação jurídica merecem ser exaltadas, dado que as soluções encontradas em outros ordenamentos podem inspirar a formulação de novas ideias, mais adequadas ao sistema sócio jurídico pátrio.

O principal objetivo da pesquisa foi explanar, de jure constituendo, os benefícios da extensão do instituto da falência à pessoa natural que se encontre em situação de superendividamento. $\mathrm{O}$ termo falência da pessoa natural ainda é um campo muito incipiente e pouco explorado, cujos estudos escassos tornam-se dignos de novas pesquisas. A falência é um instituto empresarial que consagra, no ordenamento jurídico contemporâneo, uma preocupação com a defesa daqueles impossibilitados de receber seus créditos. Trata-se de um processo de execução coletiva dos bens do devedor, decretado judicialmente, ao qual concorrem todos os credores, que buscam no patrimônio disponível, saldar o passivo em rateio, observadas as preferências legais.

A regulamentação do superendividamento, se adotada no Brasil, poderia mesclar o modelo francês, combinando a prevenção e o tratamento prioritariamente em sede extrajudicial, com o modelo norte-americano de decretação judicial da falência da pessoa natural. Se o passivo exigível do consumidor superendividado suplantar o montante total do ativo realizável, naturalmente seria bem melhor que o próprio devedor, no momento ideal, tomasse a medida necessária legal para se proteger de execuções exageradas típicas do procedimento da insolvência civil, que o forçariam a tomar decisões em caráter de urgência para evitar a perda desorganizada dos bens. Assegurar a proteção do consumidor de crédito e prevenir o endividamento excessivo, através das soluções apresentadas e de inúmeras outras que não foram aqui apresentadas devido à grandiosidade do tema, é sinônimo de efetivar o princípio da dignidade da pessoa humana nos contratos de concessão de crédito.

Por todo o exposto, é possível concluir que a extensão do instituto da falência da pessoa natural viria a preencher essencial lacuna no ordenamento jurídico brasileiro, propondo alternativas viáveis e realistas para o tratamento do superendividamento como fenômeno social e jurídico, e, principalmente, regulando de forma eficaz a sua prevenção, a partir de medidas que promovam a correta instrução do consumidor e incentivem o 
pagamento à vista, bem como estabelecendo como base os deveres de conduta decorrentes da boa-fé objetiva e da lealdade nas práticas das instituições financeiras.

\section{REFERÊNCIAS}

ARNOLDI, Paulo Roberto Colombo. A nova lei concursal brasileira: Lei $\mathrm{n}^{\circ} 11.101$ de 09 de fevereiro de 2005 - análises e reflexões. Ribeirão Preto: Lemos e Cruz, 2007.

BRASIL. Lei $n^{\circ}$ 8.078, de 11 de setembro de 1990. Diário Oficial da União, Brasília, DF, 11 set. 1990. Disponível em: <http://www.planalto.gov.br/ccivil_03/Leis/L8078.htm>. Acesso em: 23 nov. 2015.

BRITO, Alírio Maciel Lima de; DUARTE, Haroldo Augusto da Silva Teixeira. O princípio da vulnerabilidade e a defesa do consumidor no direito brasileiro. In: Revista Jus Navigandi, Teresina, ano 11, n. 1109, 15 jul. 2006. Disponível em: 〈http://jus.com.br/artigos/8648>. Acesso em: 24 nov. 2015.

CAMPOS, Fânora Almeida; MIGUEL, Laila Natal. O superendividamento à luz do projeto de lei de reforma do Código de Defesa do Consumidor. Disponível em: $<$ http://brasilcon.org.br/arquivos/arquivos/5c6efedb94cf7f7f691d5a1ff905b234.pdf >. Acesso em: 08 nov. 2015.

GONTIJO, Patricia Maria Oliva. Crédito e superendividamento: uma análise em busca da concretização do princípio da dignidade da pessoa humana. In: Anais do XIX Encontro Nacional do CONPEDI, Fortaleza, jun. 2010. Disponível em: <http://150.162.138.7/documents/429>. Acesso em: 08 nov. 2015.

MAMEDE, Gladston. Manual de direito empresarial. 7. ed. São Paulo: Atlas, 2013. p. 415.

MARQUES, Claudia Lima; CAVALLAZZI, Rosângela Lunardelli. Repensando o direito do consumidor: balanço do código de defesa do consumidor e o necessário diálogo das fontes na perspectiva de consolidação normativa do direito do consumidor. In: Revista Jurídica da Presidência, Brasília, n. 90, v. 10, p.01-38, abr./maio, 2008. Disponível em: $<$ https://revistajuridica.presidencia.gov.br/ojs_saj/index.php/saj/article/view/256>. Acesso em: 09 nov. 2015.

MARQUES, Maria Manuel Leitão. O endividamento dos consumidores. Lisboa: Almedina, 2000. p. 2.

MENEZES JÚNIOR, Eumar Evangelista de; AMARAL, Nathália de Faria Rezende; SANTOS, Luana de Miranda; CARVALHO, Antônio Alves de. O superendividamento de vulneráveis e os contratos bancarios de mútuo onerosos. In: Revista Jurídica (UniEVANGÉLICA), Anápolis, ano XIV, n. 22, v. 1, p. 1-123, jan./ jun., 2014. Disponível em:

<http://revistas.unievangelica.edu.br/index.php/revistajuridica/search/authors/view?firstName $=$ Luana $\&$ middleName $=\&$ lastName $=$ de $\% 20$ Miranda $\% 20$ Santos $\&$ affiliation $=\&$ country $=>$. Acesso em: 08 nov. 2015.

METTE, Frederike Monika Budiner; MATOS, Celso Augusto de. Comportamento do consumidor endividado: um estudo com indivíduos de baixa renda. Disponível em: 
<http://www.anpad.org.br/admin/pdf/2014_EnANPAD_MKT1200.pdf >. Acesso em: 22 fev. 2015.

MIRANDA, Pontes de. Comentários ao Código de Processo Civil. Rio de Janeiro: Forense, 1976. v. XI, p. 203. Apud TAVARES JUNIOR, Homero Francisco. Execução por quantia certa contra devedor insolvente: as interfaces de um procedimento comumente esquecido pelos operadores do direito. Disponível em: <http://www.escolamp.org.br/arquivos/revista_23_07.pdf>. Acesso em: 23 nov. 2015.

MORKING, Francelize Alves. Os batalhadores brasileiros e o superendividamento: considerações sobre os limites na materialização de direitos fundamentais. In: Revista Espaço Acadêmico, $\mathrm{n}^{\circ}$ 170, jul./2015. Disponível em: <http://www.periodicos.uem.br/ojs/index.php/EspacoAcademico/article/viewFile/26715/1486 8>. Acesso em: 23 nov. 2015.

OLIVEIRA, Juliana Andréa. O superendividamento do consumidor: aspectos conceituais e mecanismos de solução. In: Lex Humana, n. 1, v. 3, p. 92, 2011. Disponível em: $<$ http://seer.ucp.br/seer/index.php?journal=LexHumana\&page=article\&op=view \&path\%5B\% 5D=108>. Acesso em: 10 nov. 2015.

PANDORI, Giancoli, Brunno. O superendividamento do consumidor como hipótese de revisão dos contratos de crédito. Porto Alegre: Verbo Jurídico, 2008. Apud SCHMIDT NETO, André Perin. Superendividamento do consumidor: conceito, pressupostos e classificação. Disponível em: <http://www4.jfrj.jus.br/seer/index.php/revista_sjrj/article/viewFile/36/34>. Acesso em: 10 nov. 2015.

PEREIRA, Wellerson Miranda. Superendividamento e crédito ao consumidor: reflexões sob uma perspectiva de direito comparado. In: Âmbito Jurídico, Rio Grande, ano X, n. 45, set. $2007 . \quad$ Disponível em: <http://www.ambitojuridico.com.br/site/index.php?n_link=revista_artigos_leitura\&artigo_id=2229>. Acesso em nov. 2015.

SOARES, Paulo Brasil Dill; JAEGER, Amanda Marçal Sève; SILVA, Gisele Loureiro da. A mediação como solução dos conflitos decorrentes do superendividamento nas relações de consumo: estudo comparativo dos sistemas americano e europeu. In: Revista Direito em (Dis)Curso, Londrina, n. 2, v. 5, p. 114-129, jul./dez. 2012. Disponível em: <http://www.uel.br/revistas/uel/index.php/rdd/article/view/10761>. Acesso em: 08 nov. 2015.

TEIXEIRA, Rodrigo Valente Giublin; SONCIN, Juliano Miqueletti. O endividamento do consumidor brasileiro e a ofensa ao princípio da dignidade humana. In: Revista de Estudos Jurídicos (Faculdade Maringá), n. 25, jan./jun. 2015. Disponível em: <http://www.actiorevista.com.br/index.php/Actio/article/view/20>. Acesso em: 08 nov. 2015.

TEPEDINO, Gustavo. As Relações de Consumo e a Nova Teoria Contratual. Disponível em: 〈www.tepedino.adv.br/wp/wp-content/uploads/2012/09/biblioteca6.pdf>. Acesso em: 23 nov. 2015.

THEODORO JÚNIOR, Humberto. A insolvência civil. São Paulo: Forense, 1980. 